\title{
Komplex egészségfejlesztési beavatkozások lehetséges prevenciós megközelítései
}

\author{
Possible prevention approaches for complex health promotion \\ interventions
}

\author{
Szerző: Járomi Éva ${ }^{a} \bowtie$, Kimmel Zsófiab \\ a: Országos Közegészségügyi Intézet, b Emberi Eröforrások Minisztériuma
}

Beküldve: 2017.07.12.

doi: 10.24365/ef.v58i2.164

\begin{abstract}
Háttér: A különböző prevenciós tevékenységek eredményessége eltérő lehet attól függően, hogy az egész populációra vagy csupán egy adott (kockázati) csoportra fókuszál. Emiatt fontos megkülönböztetnünk és megismernünk a különféle megközelítések potenciális előnyeit és hátrányait.

A közlemény célja a különböző populációs és kockázat alapú prevenciós megközelítések bemutatása, alkalmazhatóságának vizsgálata az egészségnyereség maximalizálása érdekében.

Módszer: A populációs, kockázat-alapú, egyénre és különböző társadalmi csoportokra irányuló prevenciós megközelítésekről a hazai és nemzetközi adatbázisokban (PubMed, Science Direct, Medline), valamint a közlemények irodalomjegyzékeiben fellelhető szakirodalom áttekintése.

Eredmények: Az egészségfejlesztésnek számos megközelítése különböztethető meg a beavatkozások célja alapján. A megközelítések ennek alapján színtér alapú, kockázati, populációs és szubpopulációs típusúak lehetnek.

Következtetések: A lakosság és az egyes társadalmi csoportok egészségnyereségének maximalizálása érdekében több szinten megvalósuló, egyéneket és különböző (sérülékeny) társadalmi csoportokat célzó, kockázatalapú, valamint a teljes populációra ható megközelítésre alapozott beavatkozások komplementer alkalmazására van szükség.
\end{abstract}

Kulcsszavak: egészségfejlesztés, kockázat alapú megközelítés, populációs megközelítés, szubpopulációs megközelítés, Geoffrey Rose

Background: The efficiency of prevention programs can be different depending on population or high-risk focus. Because of this, it is important to distinguish and recognize the potential advantages and disadvantages of the different approaches. The aim of this paper is to present the diverse population and high-risk strategies and examine their applicability to maximize health benefits.

Method: an overview of prevention strategies focusing on the population, high-risk, individuals and different social groups, based on national and international databases (PubMed, Science Direct, Medline) and literature.

Results: Health promotion has many different approaches depending on the interventions used. Therefore, we can determine different approaches, such as high-risk, settings based, population and sub-population strategies.

Conclusion: To maximize health benefits of the population and different social groups, we need to design and apply interventions with a focus on individuals, different social groups, high-risk and population strategies.

Keywords: health promotion, high-risk strategy, population strategy, sub-population strategy, Geoffrey Rose 


\section{BEVEZETÉS}

A népegészségügyi beavatkozások hatásossága meglehetősen változatos képet mutat hazánkban és a nemzetközi gyakorlatban egyaránt. A különböző prevenciós tevékenységek eredményessége szintén eltérő lehet attól függően, hogy az egész populációra vagy csupán a társadalom egy adott csoportjára fókuszál. Ily módon fontos megkülönböztetnünk és megismernünk a különféle megközelítések alkalmazásának potenciális előnyeit és hátrányait.

A hazai prevenciós programok áttekintése, illetve áttekinthetetlensége egyértelmúen jelzi, hogy a prevenciónak Magyarországon nincs megfelelően kidolgozott stratégiája, ebből következően hatásosan, illetve hatékonyan múködő szervezeti kerete sem. Érvényesnek látszik Ádány 1998-ban a magyarországi prevencióról írt értékelése: a hazai gyakorlat - a népegészségügyi szűréseket kivéve - nem feladatok és funkciók mentén jött létre, ezért átfedések és hiányosságok egyaránt tapasztalhatók. ${ }^{1}$

Hazánkban, ahogy más fejlett európai országban is, a nem fertőző krónikus betegségek jelentik a legnagyobb népegészségügyi problémát. ${ }^{2}$ Néhány, főleg a szív- és érrendszeri megbetegedések területén végzett megelőzési és gondozási programon kívül kevés olyan kezdeményezés történt, amely ne klinikai problémaként kezelte volna a krónikus nem fertőző betegségek elleni küzdelmet. Következésképp, jelentős forrásokat használtak fel főként a kifinomult diagnosztikai és terápiás technológia kialakítására, fejlesztésére és annak fenntartására. Az elmúlt évtizedek adatai azonban meggyőző módon mutattak rá arra, hogy a nem fertőző krónikus betegségek jelentős része megelőzhető, kialakulásának időpontja elhalasztható.

Ádány értekezésében ${ }^{1}$ továbbá azt is említi, hogy a prevenciós fókuszú beavatkozások képezik az ágazati stratégia fő prioritását, azonban annak javasolt megközelítését a stratégia nem tárgyalja. Ennek egyik oka lehet a prevenció és a népegészségügyi fogalmak különböző értelmezése, az egészségmagatartás és a nem fertőző megbetegedések kialakulásának kockázatát meghatározó tényezők közötti összefüggések figyelmen kívül hagyása. Kiemelten fontos tényezőnek tartja Ádány, hogy a népegész- ségügyi szakembereken túl az egyéb területek szakemberei és a politikai döntéshozók is tisztában legyenek ezekkel a definíciókkal és e területek összefüggéseivel. Ezért érthető, hogy a népegészségügyi stratégia megalkotásakor fontos a népegészségügyet érintő összes terület fejlesztésének szükségessége, beleértve az egészségfejlesztést, a betegségmegelőzést és az egészségvédelmet egyaránt.

A népegészségügy fogalmának ma is érvényes megfogalmazását az Egészségügyi Világszervezet (továbbiakban: EVSZ) alkotta meg 1988-ban: a népegészségügy a társadalom szervezett tevékenysége, mely a betegségek megelőzésének, az élet meghosszabbításának és az egészség fejlesztésének elméletét és gyakorlatát képezi. Hazánkban az 1997. évi CLIV. törvény népegészségügyről szóló III. fejezetének 35. B (1) pontja is e megfogalmazás mentén került kialakításra.

A közlemény célja - a fenti definícióból kiindulva - a népegészségügy szervezett tevékenységének különböző prevenciós szinteken történő megközelítésének bemutatása, különös tekintettel a populációs és kockázat alapú megközelítésekre, alkalmazhatóságuk vizsgálatára, mindezt az egészségnyereség maximalizálása érdekében.

\section{MÓDSZER}

A közlemény a különböző primer prevenciós megközelítésekről rendelkezésre álló hazai és nemzetközi adatbázisokban fellelhető (PubMed, Science Direct, Medline) szakirodalom összegyűjtésén és áttekintésén, valamint a kigyűjtött írások irodalomjegyzékeinek áttekintésén alapul. A szakirodalmi keresés a következő kulcsszavakkal történt: health promotion, high-risk strategy, population strategy, sub-population strategy, Geoffrey Rose.

\section{EREDMÉNYEK}

A prevenciós megközelítéséket befolyásoló néhány alapdokumentum

A megelőzés szemléletének eredete 1974-re nyúlik vissza, mikor Marc Lalonde kanadai egészségügyi és 
népjóléti miniszter egy jelentést adott ki „A kanadaiak egészségi állapotának új távlata” címmel. A tanulmány arra hívta fel a figyelmet, hogy a betegségek, halálozások hátterében biológiai, környezeti és életmódbeli tényezők húzódnak meg, ezért az egészségügyi szolgáltatások finanszírozása mellett fontos a környezeti és szociális tényezők támogatása is, valamint felhívta a figyelmet a betegségek megelőzésére, azok kezelésével szemben. ${ }^{3}$

A Lalonde riport megjelenésével párhuzamosan, Thomas Mckeown publikálta cikksorozatát, melyben rávilágít arra, hogy az egészségben bekövetkezett pozitív irányú változás elsősorban a szociális és gazdasági fejlődésnek volt köszönhető, nem az egészségügyi szolgáltatások minőségében bekövetkezett javulásnak, mely tévhit azonban az egészségügyi szolgáltatások helytelen finanszírozásához és elosztásához vezetett. ${ }^{4}$

Annak ellenére, hogy sokan kritizálták McKeown következtetéseit, azt mindenki elismerte, hogy a 20. század közepén bekövetkezett halálozás csökkenésében némi szerepet játszottak a kuratív orvoslást segítő szabályozások. McKeown elmélete, bár több ponton vitaható, mégis egy máig is érvényben lévő kérdést feszeget. Milyen beavatkozások bizonyulnak hatékonynak a népegészségügyben: az egyéneket célzó vagy a széleskörű beavatkozások, amelyek szociális, a politikai és gazdasági erőforrások újraosztásával a teljes populációra hatással vannak?

A fentiekhez hasonló, a betegségek kezelésétől távolodó és azok kialakulásáért felelős tényezők alakításának irányába mutató szemléletváltás már az EVSZ-en belül is megtörtént 1986-ban. A kanadai Ottawában megrendezett első nemzetközi egészségfejlesztési konferencia záródokumentuma, az Ottawai Karta a mai napig alapdokumentuma és referenciája az egészségfejlesztésnek. A Karta jól ismert definíciója szerint „az egészségfejlesztés az a folyamat, amely módot ad az embereknek, közösségeknek egészségük fokozott kézbentartására és tökéletesítésére. A teljes fizikai, szellemi és szociális jólét állapotának elérése érdekében az egyénnek vagy csoportnak képesnek kell lennie arra, hogy megfogalmazza és megvalósítsa vágyait, kielégítse szükségleteit, és környezetével változzék vagy alkalmazkodjon ahhoz." ${ }^{\text {(9.o.) }}$
Az EVSZ javaslata alapján erősíteni és fejleszteni kell az ágazatok közötti együttmúködést az egészségfejlesztéssel kapcsolatos szabályozások és szolgáltatások fejlesztése során. A beavatkozások célja elsősorban az egyenlőtlenségek csökkentése, valamint az egészséget elősegítő környezet kialakítása kell, hogy legyen, ezáltal csökkentve a nem fertőző betegségek előfordulását és a lakosság jól-létének javítását. ${ }^{5} \mathrm{~A}$ támogató környezet megteremtésén és a közösségek erősitésén keresztül cél az egyének és a lakosság felruházása az életen át tartó egészséges életmód és magatartás lehetőségével. A 2016 novemberében rendezett Shanghai Egészségfejlesztési Konferencia nyomán létrejött nyilatkozat is ezt támasztja alá: kimondják ugyanis, hogy a helyi szintú kezdeményezések hatékonyan múködnek és a közösségek és városok az egészség különösen fontos helyszíneit képezik. ${ }^{6}$

Hagyományos egészségnevelés, felvilágosítás

A populáció alapú megközelítés mellett létezik egy ún. hagyományos egészségnevelésen, felvilágosításon alapuló szemlélet, mely azon az elméleti megfontoláson alapul, hogy az ember viselkedése racionális döntések sorozatának eredménye. Ebből kiindulva a nagyobb tudás a helyes döntéseket és a helyes egészségmagatartás kialakítását eredményezi. E megközelítés szerint a tudás az elsődleges meghatározó tényező, melynek növelésével a viselkedés pozitív irányban változik. Ezeket általában egészségnevelő kampányokkal, alkalmi jelleggel megszervezett iskolai felvilágosító előadásokkal, brosúrákkal igyekeznek elérni, melyek például, a dohányzás veszélyeire, az egészséges táplálkozásra és a fizikai aktivitás növelésére hívják fel a lakosság figyelmét. Ezzel szemben az egészségnevelési tananyagok többnyire az elrettentés eszközét alkalmazzák a helytelen életmód veszélyeire történő figyelemfelhívás során, melyek hatástalansága, sőt olykor ellentétes hatása egyre inkább beigazolódik (például, a dohánytermékek dobozán feltüntetett tájékoztató, elrettentő üzenetek ellenére a nők körében továbbra is emelkedik a dohányosok aránya.)

A megközelítés fő jellemzője, hogy többnyire egyirányú kommunikációt, közlési formát alkalmaz, nélkülözve a hallgatóság aktív bevonását a folyamatba. ${ }^{7}$ 


\section{Színtér alapú megközelítés}

A színtér alapú megközelítés tárgyalása előtt fontos lehet tisztázni az egészségfejlesztési színtér fogalmát. A színtér programok az Ottawai Charta nyomán jöttek létre. A színtér olyan helyszín, „ahol az emberek a mindennapi életüket élik, és ahol részvételük a saját egészségük fejlesztésében „magától értetődő." 8 (6.o.) Olyan „hely”, ahol az egyén és az esetleges probléma is „jelen van”, így, ahová az előzőekből adódóan a beavatkozást is el kell juttatni. A normák és a szocializáció a különböző színtereken alakulnak ki, ahol az egyén kapcsolatba kerül a társadalom különböző csoportjaival. Az egészségfejlesztésben alkalmazott színtér-megközelítés a mindennapi élet színtereinek tekint szúkebb értelemben minden önkéntes közösségi (informális csoportos formában történő) rendszeres aktivitást. Tágabban értelmezve, azon formális csoportok is ide sorolhatók, ahol mód van az informális kapcsolatok erősitésére, amelyek által a közösségi támogatottság és ily módon az egészség is fejleszthetővé válik (például, oktatási intézmények, munkahelyek, speciális célcsoportot ellátó intézmények, kistelepülések, településrészek, lakótömbök, stb.). Az egyes színterek további jelentőségét az adja, hogy nagy létszámú társadalmi csoportok csak egyes, speciális színtereken érhetőek el.

A lokális színterek egészségtervei összekapcsolhatók, kiegészítik egymást és megalapozzák a felsőbb szintű, komplexebb egészségterveket. Egy városi vagy járási egészségterv akkor értelmezhető igazán, ha a lokális színterek kompetenciájukba nem tartozó problémáit térképezi fel és azok kezelésére törekszik. Egy kis közösség (színtér) szerepe, illetve felelőssége, hogy úgy határozza meg önmaga szükségleteit és igényeit, hogy a felsőbb szinten tervezett koncepciók és fejlesztési stratégiák, tervek azt számításba is tudják venni. Ily módon biztosítható, hogy a helyben meglévő források kiegészítése, támogatása felhasználható és fenntartható módon valósuljon meg. ${ }^{8}$

\section{Populációs megközelítés}

Ádány Róza 1998-ban az előzőeken túl kétféle megközelítést említ: az egyénre és a populációra alapozott megelőzést. Az első esetben - megfogalmazása szerint - a megelőző stratégia először azonosítja a fokozott kockázatnak kitett egyéneket, majd bizonyos védelmet kínál számukra. A fokozott kockázatnak kitett egyénekre irányuló („veszélyeztetett csoport”) preventív stratégiák célja a magas kockázatnak kitett egyének azonosítása, valamint a kockázatuk csökkentése. Az egész népességet célzó „populációra alapozott" stratégia az előzővel ellentétben a populációra jellemző kockázati tényezőiket szerves egészként próbálja meg kezelni, a kockázati tényezők populációs eloszlását kedvező irányba módosítani.

Mindkét preventív stratégia középpontjában a kockázati tényező okozta kockázat kivédése, megelőzése áll. Végeredményben tehát mindkettő a népesség egészségi állapotán szándékozik javítani.

Különbségként jegyezhető meg azonban, hogy a fokozott kockázatnak kitett egyénekre irányuló preventív stratégia a legnagyobb expozíciónak kitett egyénekre összpontosít. Alkalmazásának elengedhetetlen előfeltétele a fokozott kockázatnak kitettek ( $a$ „rizikó-csoport”) azonosítása. Az egész népességet célzó preventív stratégia a kockázati tényezők populációs szintjének általános csökkentésével szándékozik a lehetséges kockázatok csökkentését elérni és ezáltal a népesség egészének egészségi állapotát javítani (egészségmegőrzés és betegség megelőzése); mivel ez a stratégia a népesség egészére irányul, nincs szükség a célcsoportok előzetes azonosítására. ${ }^{1}$

Goffrey Rose, epidemiológus "Sick Individuals and Sick Populations" címú, 1985-ben közreadott értekezésében Roy Acheson által feltett kérdése nyomán a megbetegedések kialakulásának okai közötti összefüggéseket vizsgálta. Nevezetesen, hogy „Miért pont ezek a paciensek betegedtek meg és miért éppen most?" ("Why did this patient get diseases at this time?") Rose tehát a megbetegedések egyéni és populációs szinten megjelenő okait vizsgálta. Nem csak arra a kérdésre kereste a választ, hogy „Mi a diagnózis és hogyan kezeljük?", hanem azt is, hogy "Miért pont most történt és hogyan lehetett volna megelőzni?” és hogy „Miben különböznek a beteg és az egészséges egyének?" Számos kohorsz vizsgálat irányult az elmúlt években ezen kockázati tényezők felkutatására. Ezek célja, hogy választ ta- 
láljanak arra a kérdésre, hogy bizonyos egyének miért fogékonyabbak a betegségekre, másokkal szemben, akik egészségesek maradnak. Miért nincs magas vérnyomás-betegség például, Kenyában és miért olyan gyakori Londonban? A válasznak a lakossági átlagot meghatározó tényezőkhöz van köze. Az, hogy mi különbözteti meg a két csoportot, annak semmi köze az egyéni jellemzőkhöz, a teljes eloszlás eltolódásához viszont annál inkább a - népesség egészét érintő, vérnyomást befolyásoló - hatások eredőjeképpen. Az egyének ezen jellemzőinek előfordulási valószínúségét a környezeti és egyéni faktorok változása befolyásolhatja. Minden olyan tényező, mely módosítja az eloszlást, az az egyénekre kifejtett hatáson keresztül változtatja meg a népességbeli eloszlást. ${ }^{9}$

A vérnyomás „normál” laboratóriumi értékének definícióját is körüljárja, amely többnyire a helyi populáció körében leggyakrabban előforduló értéket jelöli. Így tehát azokat nevezik „,normál vérnyomással” rendelkezőknek, akik nem térnek el a helyi kortársaik értékétől. Hazánkban például a 140/90Hgmm alatt mért vérnyomás értékeit tekintik „,normál” értéknek, míg az USA-ban számos vizsgálat irányult az utóbbi időben a vérnyomás határértékére vonatkozóan, amely ennek a határértéknek az újradefiniálását (120/80 Hgmm) sürgeti. ${ }^{10} \mathrm{Az}$, hogy mit tekinthetünk a vérnyomás tekintetében „normál” értéknek tehát, számos tényező függvénye (például, kor, nem), melyek mind befolyásolják ezeket az értékeket.

A populációs stratégia/megközelítés tehát egy kísérlet az egyes betegségek incidenciáját meghatározó tényezőinek kontrollálására, annak érdekében, hogy csökkentsék a kockázati tényezők átlagos szintjét, valamint az expozíció teljes eloszlását egy kedvezőbb irányba befolyásolják.

A hagyományos „közegészségügy” ehhez kapcsolódóan a környezeti szabályozást alkalmazza a környezet egészségbarát ki- illetve átalakítása útján (pl. tiszta ivóvíz, megfelelő csatornázás). Modern formájában megkísérli helyettesíteni (kevésbé sikeresen) a viselkedés néhány társadalmi normáját, valamint az egészséges viselkedés és az annak megfelelő választások elősegítését. Az egészséggel kapcsolatos kockázatokkal szemben történő passzív védelem ugyanis sokkal hatékonyabbnak tûnik, mint az aktív viselkedés megváltoztatásának elősegítése. $^{11}$

Rose állítása szerint, ha a megbetegedési kockázat széles körben elterjedt, az intézkedések, amelyek mindenki kockázatát csökkentik, sokkal hatékonyabbak a betegségteher csökkentésében, mint a magas kockázatú megközelítés, amelyben az intézkedések csupán azokat az egyéneket célozzák, akik lényegesen nagyobb megbetegedési kockázattal rendelkeznek. Mivel, ha a megbetegedések aránya növekszik a kockázati tényezők növekvő szintjével párhuzamosan, akkor az emberek nagyobb számában történő, mérsékeltebb kockázatemelkedése esetén (is) általában több megbetegedéssel járulnak hozzá a teljes betegségteherhez, mint az alacsonyabb létszámmal bíró, magas kockázattal rendelkező társaik.

A népesség nagy százalékát elérő beavatkozások, a tömegeket célzó megelőző intézkedések alkalmazása számos jelentős előnnyel bír:

- Radikálisak: kísérletet tesznek a betegség kiváltó okainak megszüntetésére, amelyek a megbetegedést gyakorivá teszik.

- A populáció hatalmas részét elérik, olykor a vártnál is nagyobb részét, ily módon a megbetegedések incidenciája csökkenthető.

- Elősegítik a megfelelő viselkedést: ha a dohányzásmentesség vagy például, a diéta válik társadalmilag elfogadott normává, akkor az egyének meggyőzése kevésbé szükségszerú. Ezáltal az új táplálkozási igényekhez/szokásokhoz adaptálódnak az élelmiszergyártók is. Ily módon az egyénnek nem szükséges túlságosan nagy erőfeszítéseket tennie a diéta fenntartásához.

Hátrányai:

- Az egyén számára alacsonyabb haszonnal bírnak. A prevenciós paradoxon szerint azok a prevenciós intézkedések, amelyek populációs szinten nagy haszonnal járnak, az azokat alkotó egyének számára keveset nyújtanak, különösen rövidtávon (például, védőoltások, kötelező biztonsági öv használat, és napjainkban számos életmód jellemző).

- Alacsony motiváció az egyének és az orvosok körében, amelynek következtében az egyé- 
nek számára rövidtávon hatástalanok. Az orvosok által pácienseknek nyújtott tanácsok megfogadása pedig kisebb valószínűséggel eredményez azonnali egészségjavulást.

- Az orvosok/egészségügyi dolgozók számára nehéz az egészséget populációs kérdésként, és nem pedig az egyén saját problémájaként értelmezni.

- Alacsony egyéni hasznot eredményeznek, ezzel szemben jelentős költséget generálnak. ${ }^{9}$

Rose publikációja tehát a betegségmegelőzés új stratégiájának kiindulópontját képezte. A hatékony prevenciós lehetőségekről való gondolkodásban úttörő volt. Munkájával egyfajta prevenciós útmutatót kívánt nyújtani. A betegségek egyéni eseteinek okát, valamint annak incidenciáját vizsgálta egy adott populációban. Emellett a kockázatalapú és a populációalapú megközelítés lehetséges előnyeit és hátrányait vette számba. ${ }^{12}$

\section{A kockázat alapú (rizikócsoportos) megközelítés}

A megközelítés elméleti alapját a korai szűrés során azonosított egészségproblémákkal, rizikófaktorokkal rendelkező csoportokat célzó prevenciós és egyéb intervenciós tevékenységek képezik. Ily módon a krónikus, nem fertőző megbetegedésekkel, illetve a társadalmi-gazdasági helyzet szempontjából veszélyeztetett kockázati csoportok megfelelő azonosításával lehetőség nyílik a célcsoportra jellemző egészségmagatartás megváltoztatását célzó megelőzési programok és egészségjavító beavatkozások kialakítására.

Ez a fajta megközelítés a hagyományos, medikális prevenciós megközelítésen alapul, amely a kockázat eloszlásának egyfajta „csonkolása”. Számos speciális megelőző beavatkozást kínál minden magas kockázatú egyén számára (például, alacsony súllyal született csecsemők, vagy egyéb más, különösen veszélyeztetett, csoportok, mint például a hajléktalanok vagy a szexmunkások).

Több világos és fontos előnnyel bír:

- a kockázati csoportokra irányul, betegség specifikus,

- a források költség-hatékony felhasználása jellemzi,

- fenntartja az orvos motivációját, alkalmazása esetén alacsony a kockázati arány (adott csoportban azonos kockázat).

Az elsődleges előnye, hogy a beavatkozások az egyént célozzák. Például, könnyebb egy köhögéssel vagy károsodott légzésfunkcióval küzdő dohányost leszokásra ösztönözni, hiszen már számára is felismerhető, speciális indoka van a dohányzás elhagyásának. Akárcsak a magas vérnyomásban szenvedők esetében a sófogyasztás csökkentésének.

A kockázatalapú megközelítés fő tevékenységeinek egyike a szűrés, amely azonban számos hátránnyal bír:

- Többnyire a betegség legkisebb kockázatának kitett egyéneket éri el. Emellett olyanokat, akik magas kockázati csoportba sorolhatóak, de nem áll rendelkezésre megfelelő kezelés a kockázatuk csökkentésére.

- Palliatív és ideiglenes, nem radikális/kevésbé mélyreható: nem a betegség okainak megszüntetésére irányul, hanem azon egyének azonosítására, akik különösen fogékonyak a fentebb említett betegségekre.

- A megközelítés alkalmazása esetén korlátozott lehetőség áll rendelkezésre az egyének és a populáció számára (a jövőben kialakuló betegség előrejelzésének lehetősége meglehetősen gyenge a relatív kockázati statisztikák és az abszolút kockázat között).

- A szürés mellett az egyén környezetét is meg kell szólítani/célozni a helytelen egészségmagatartás miatt, amelyet a szociális normák, a környezet, kortársak viselkedése predesztinál.

Emellett Rose tanulmányában azt is megállapította, hogy az alacsony kockázattal rendelkező emberek nagy száma több megbetegedést idézhet elő, mint azok, akik magas kockázattal rendelkeznek, de kevesebben vannak. Mivel ez a szituáció elég gyakori, ezért a magas-kockázatra alapuló stratégia korlátozott hasznosságára enged következtetni a megelőzésben. $^{9}$

\section{Szubpopulációs megközelítések}

A szubpopulációs megközelítés a népességen belüli egy-egy kiemelt alcsoportot különböztet meg. A megközelítés döntően olyan alcsoportokra vonatko- 
zik, amelyek a társadalmi erőforrások és a szolgáltatásokhoz való hozzáférés alapján (mint például, jövedelmi helyzet, egészségi állapot, foglalkoztatási státusz vagy lakóhely) hátrányosan érintettek. Azon a meggyőződésen alapul, hogy bizonyos társadalmi jelenségek gátolják az egészséget támogató erőforrásokhoz való igazságos hozzáférést, és hogy a társadalom hátrányos helyzetű tagjaira irányuló beavatkozások szükségesek az egyes csoportok egészségi állapotában megfigyelhető „szakadék” megszüntetéséhez. ${ }^{12}$

Egy másik megfogalmazás a társadalom ilyen alcsoportjait különösen sérülékeny populációként határozza meg. Az elnevezés olyan csoportokra utal, akik a társadalomban elfoglalt helyük miatt hátrányos körülmények közt élnek, és ennek következtében az egészségkockázati kitettségük a lakosság más csoportjaihoz viszonyítva nagyobb. Az Ontario Népegészségügyi Intézet által megalkotott standardokat tartalmazó kiadványában prioritást élvező populációnak nevezi a lakosságnak ezen szegmensét, amelyet szintén a marginalizálódás, a sebezhetőség vagy más kockázati tényezők alapján határozott meg. ${ }^{13}$

A különösen sérülékeny csoportok, valamint a kockázatnak kitett csoportok ugyan alapvetően különböznek egymástól, de néhány tekintetben mégis fedik egymást. Az előbbiek közös társadalmi jellemzőkkel határozhatóak meg, míg utóbbiakat egy-egy kockázati tényező magas szintű expozíciója jellemzi. Kanadában például azokat tekintik veszélyeztetett populációban élőknek, akiknél a kockázati kitettség összességében lényegesen magasabb, mint a lakossági átlag (például, a bennszülött származásúak, a szegénységi küszöbnél alacsonyabb jövedelemmel rendelkezők és a középfokú végzettséggel nem rendelkezők). Az őslakosok átlagosan számos kockázati tényezőnek vannak kitéve, de nem mindenki tartozik a magas kockázati populáció csoportjába.

A szubpopulációt célzó intézkedések lehetséges hátránya, hogy ezen populációk pozitív diszkriminációjához, stigmatizálásához vezethet. Emellett a populációs egészség szempontjából kevésbé hatásos.

Az országokon belüli társadalmi és gazdasági rétegződés megnehezíti az egymástól teljesen eltérő szubpopulációk - megelőzésről szóló médiaüzene- tek által történő - elérésének képességét. Különbségeket okoz a médiaajánlások gyakorlatban történő alkalmazásában, sőt, problémákat okoz a társadalom különböző rétegei számára a természeti, környezeti és a közösségi létesítményekhez való hozzáférés tekintetében is. A gazdasági rétegződés, mint a népesség egészségének és hosszú élettartamának meghatározó tényezője, jelentős szereppel bír. Ezek a tényezők ebben a tekintetben sokkal fontosabbak, mint a társadalom gazdagságának átlagos szintje. A szubpopulációk jelentősen eltérhetnek a közvetített ajánlásokra adott érzékenységükben, az üzenetek megértésének és adaptálásának képességében, valamint az adott csoport elérésének lehetőségeiben. ${ }^{14}$

\section{Egészséghatás piramis}

Thomas R. Frieden egy alternatív fogalmi keretet dolgozott ki ${ }^{15}$, amely a különböző (célcsoportra irányuló) népegészségügyi intézkedéseket egy 5 szintből álló piramis alakú rendszerbe ágyazva különbözteti meg egymástól. A piramis alapját a társadalmigazdasági meghatározó tényezők azonosítására tett erőfeszítések képezik. Ezt követik a népegészségügyi beavatkozások (például, tiszta ivóvíz, biztonságos úthálózat biztosítása), amelyek megváltoztatják az egyén környezetét, valamint a hosszú távú előnyökkel járó egészségvédelmi beavatkozások (például, immunizálás), ezt követi a közvetlen klinikai ellátás, majd a piramis tetején a tanácsadás és az oktatás.

A piramis legalsó szintje a társadalmi-gazdasági tényezők változását tükrözi. Itt az általános - a teljes népességre kiterjedő - beavatkozások és intézkedések találhatók (például, a szegénység csökkentése, az oktatás fejlesztése), amelyek a legkevesebb egyéni erőfeszítést igénylik, várhatóan mégis a legnagyobb populációs hatással bírnak. Mivel azonban az ezen a szinten megvalósított intézkedések a társadalom szociális és gazdasági struktúráira vonatkoznak, ellentmondásosak lehetnek, különösen akkor, ha a lakosság nem látja, hogy az ilyen beavatkozások a kormány megfelelő tevékenységi körébe tartoznának.

A következő szint olyan beavatkozásokat jelent, amelyek megváltoztatják a környezetet, annak ér- 
dekében, hogy az egészséges választás alapértelmezett lehetőség legyen, függetlenül az egyének iskolázottságától, jövedelmi helyzetétől és a szolgáltatásokhoz való hozzáférésétől. Ezen beavatkozási szint meghatározó jellemzője, hogy az egyéneknek jelentős erőfeszítéseket kell tenniük azért, hogy ne részesüljenek az intézkedések előnyeiből (például, vezetékes ivóvíz hozzáadott fluorid-tartalma, transzzsírsavak mellőzése, élelmiszerek sótartalmának csökkentése, kerékpárutak kiépítése, dohányfüstmentes helységek, stb.).

A következő - 3. szint - a hosszantartó egészségvédő intézkedéseket tartalmazza. Ezek általában kevésbé hatásosak, mint az alsó két szint által megvalósított beavatkozások, mivel az egyének közremúködését igénylik. Ilyen beavatkozások például a védőoltások vagy a dohányzásról leszokást támogató programok.

A 4. szintet a klinikai beavatkozások képezik, amelyek például, a szív- és érrendszeri betegségek megelőzésére irányulnak, és egyénenként a legnagyobb egészséghatással járhatnak. A bizonyítékokon alapuló orvosi ellátás csökkenti a betegségek terheit, azonban az ilyen beavatkozások populációs szintre összesített hatását erősen korlátozhatja a szolgáltatásokhoz való hozzáférés nehézsége, valamint az alacsony terápiahűség (például, a gyógyszerszedési problémák a magas vérnyomás és diabétesz kezelése esetében). Az orvosi ellátás eredményességének fokozása érdekében fontos a szigorú elszámoltathatóság, az igazoltan jó ellátási gyakorlatok ösztönzése (például, a vérnyomás és a koleszterin-szabályozás), valamint az ezeket támogató rendszerszintû megoldások alkalmazása (például, elektronikus nyilvántartási rendszer, pénzügyi ösztönzők). A piramis tetején (az 5. szinten) elhelyezkedő intervenciók az egyének segítésén alapulnak, a teljes lakosságra viszont kevésbé terjednek ki. Az orvos-beteg találkozásokon vagy más színtéren nyújtott tanácsadás - amelyet egyesek a népegészségügyi cselekvés lényegének tekintenek - a gyakorlatban a legkevésbé hatékony beavatkozási típusnak bizonyul. Elméletileg az ilyen univerzálisan és hatékonyan alkalmazott beavatkozásokkal hatalmas populációs hatás érhető el. A gyakorlatban, még a piramis felsőbb szintjein lévő legjobb programok is korlátozott népegészségügyi hatást érnek el, főként azért, mert nem képesek hosszabb időn keresztül fennmaradó viselkedésváltozását elérni. Ennek oka legtöbbször az egészséges életmódot támogató környezet biztosításának nehézsége. Az egyéni szintű beavatkozásoknak például az elhízás kockázatát csökkentő környezet kialakítására (könnyen elérhető, testmozgásra alkalmas sportpályák a fizikai aktivitás fokozására, vagy olcsó zöldség és gyümölcs a táplálkozás javítására) többnyire kevés vagy semmilyen hatása nincs.

Frieden szerint az egyetlen dolog, amely az egyének számára nyújtott egészségnevelés tapasztalataiból leszűrhető, hogy az csupán elvesztegetett idő. Az eredmények eléréséhez a jelentős tanácsadási és utánkövetési időszakra vonatkozó beruházásra van szükség. Ez igen nagy idő, energia és erőforrás ráfordítással jár, emellett sokkal hatékonyabb a korlátozott orvosi szolgáltatásokra és időre koncentrálni ott, ahol szükséges és ahol nagy valószínűséggel a legnagyobb előnnyel jár.

Fentiek alapján megállapítható, hogy a piramis tetejétől annak legalsó szintjéig haladva növekszik a szintekben megjelenő intézkedések populációra kifejtett hatása, illetve a politikai elköteleződés szükségessége. Ez utóbbi hiányában aligha valósulhatnának meg sikeresen ezek a beavatkozások. A piramis csúcsa felé haladva pedig az egyéni erőfeszítések szükségessége növekszik, míg a populációs szinten összesített hatásosság egyre csökken. ${ }^{15}$

\section{KÖVETKEZTETÉSEK}

Számba véve a fentieket, megállapítható, hogy a hatékony népegészségügyi beavatkozások érdekében kiemelkedően fontos azok várható hatásait előzetesen értékelni az elvárt előnyök és a megvalósítás költségének szembeállítása révén, valamint előzetes költség-hatékonyság becslés segítségével.

Emellett fontos figyelemmel lenni arra a tényre, hogy az egyén és a társadalom kollektív szokásainak, viselkedésének megváltoztatása nehezebb, mint az egészséget befolyásoló környezet átalakítása. Az egyén betegségektől való félelme azonban igen jelentős motiváló erővel bírhat (például, a tüdőráktól való félelem vezérelte dohányzás leszokást támogató programokon való részvétel). ${ }^{9,11}$ 
Hatékony populációs megközelítés eléréséhez a különböző társadalmi csoportokhoz (nemcsak a kockázati csoportokhoz) igazított tartalmú üzenetek megfogalmazása szükséges, törekedve az egyének széles körének elérésére. Ehhez figyelembe kell venni a populáción belüli társadalmi rétegeződést, ugyanis számos eltérés figyelhető meg az egyes szubpopulációk között az üzenetek megértése, adaptálásának lehetősége és az adott csoport szenzitivitása, elérhetősége tekintetében. Önmagában a médiaüzenetek nem érik el a kívánt hatást, ha az egyéneket nem sikerül közvetlenül elérni. A populációs alapú megelőző intézkedésekkel elért hatás érdekében tehát módosítani szükséges a különböző társadalmi csoportok számára címzett tartalmat, valamint széles körben elérhetővé kell tenni azt a nem kizárólag csak a magas kockázatú - csoportok számára. ${ }^{14}$

Egy Hollandiában lezajlott vizsgálatban ezeknek a populációs és kockázat alapú megközelítéseknek a prevencióhoz való hozzájárulását hasonlították öszsze 1970 és 2010 között a populáció egészségére gyakorolt hatása tekintetében. 22 preventív beavatkozást vizsgáltak meg, amelyek összesen 16 ezer halálozás és számos megbetegedés elkerülését eredményezték. Ezek közül a dohányzás elleni küzdelem és a közúti közlekedési biztonságot javító intézkedések bizonyultak a legnagyobb hatásúaknak. A kockázat alapú megközelítések, mint a magas vérnyomás felismerése és visszaszorítása, valamint a daganatos megbetegedések szűrése csupán az egynegyedét képezték a teljes egészségnyereségeknek. Ehhez kapcsolódva idézhető Mackenbach és munkatársai, akik szerint jelentősen nagyobb egészségnyereség érhető el a populációs megközelítéssel, mint a kockázati alapú prevenciós megközelítések alkalmazásával. A prevenciós stratégiák tervezésekor tehát az egészségnyereség maximalizálása érdekében a populációs, kockázati csoportok igényeit figyelembe vevő megközelítések kombinációjára, valamint a különböző társadalmi csoportok sajátosságaira irányuló, ennek elvei mentén megtervezett beavatkozások kidolgozására van szükség. ${ }^{11}$

A prevenciós stratégiák tervezésekor kiemelkedően fontos a társadalmi-gazdasági kontextus figyelembe vétele. Így jártak el 1972-ben North Karelia projekt tervezése és megvalósításakor is, ahol már holisztikusan, azaz több ágazat bevonásával, az egyént körülvevő környezet szerepének figyelembe vételével szemlélték a prevenciós programokat. A populációs szintű beavatkozások mellett számos társadalmi csoport számára megfogalmazott (média) üzeneteket alkalmaztak, kiegészítve az orvos-beteg találkozások alkalmával történő kommunikációt. Ily módon igyekeztek biztosítani a projekt átfogó, közösségi fókuszú megvalósítását, amelyben részt vett a nonprofit szektor, az ipar, a média és a közpolitika is. A projektet követően a szív- és érrendszeri megbetegedések száma szignifikánsan csökkent a lakosság körében. ${ }^{12}$

Marmot szerint a társadalom egészére kiterjedő cselekvésre van szükség, az egészségügyi rendszer eredményességét meghatározó társadalmi tényezőkre összpontosítva". ${ }^{16}$ Véleménye szerint "(...) az egészség terén mutatkozó egyenlőtlenségek kezelése érdekében a legfontosabb stratégiák azok, amelyek egyetemesek (...). ${ }^{17}$ Kiemelkedően fontos, hogy az intervenciók ágazatköziek és részvételen alapulóak legyenek. A sérülékenységet okozó alapvető okok ${ }^{1}$ a mindennapi életben gyökereznek, és ezek enyhítése elsősorban az egészségügyi ágazaton kívül esik (például, az analfabetizmus megakadályozása/megelőzése). Ilyen esetekben az egészségügyi ágazat szerepe nem annyira nagy a társadalmi meghatározók alakításába történő közvetlen befektetésben, mint a menedzselésben és az egyéb egyenlőtlenségek csökkentésében. ${ }^{14}$

A társadalmi és gazdasági változások elérése alapvető társadalmi átalakulást igényel. A kontextusváltás gyakran vitatott, amelyet például Magyarországon a dohányzást vagy a mesterséges transzzsírsav-szabályozást érintő törvényhozás körüli viták bizonyítanak. Az alapvető társadalmi változások megteremtésének legfontosabb akadálya azonban gyakran nem a pénzhiány, hanem a politikai akarat hiánya. Az egészségügyi ágazat szerepe megteremteni az ágazatokon átívelő támogatást és kialakítani, fejleszteni a változásokhoz szükséges partnerségeket. Annak ellenére, hogy társadalmi és környezeti változások hatékonyabbak a népegészségügy fejlesztésében, ez nem jelenti azt, hogy más

\footnotetext{
${ }^{1}$ Erről részletesebben lásd ebben a lapszámban Csizmadia P. Az egyenlôtlenségek alapvető társadalmi okai és az elmélet alkalmazási lehetőségei az egészségügyi szakpolitikákban című cikkét.
} 
beavatkozásokat figyelmen kívül kellene hagyni. Például, az óvszerhasználat ösztönzése korlátozott hatékonysággal bír, azonban csökkentheti a HIV-fertőzést. Különböző népegészségügyi problémák esetén tehát, különböző szintű és típusú beavatkozások lehetnek a leginkább hatékonyabbak vagy kivitelezhetők bármely/adott környezetben. ${ }^{15}$

Az előzőek alapján fontos továbbá megállapítani, hogy a rövidtávon megvalósuló projektek helyett vi- lágos, megalapozott, hosszú távú prevenciós stratégiára van szükség, a fő beavatkozási prioritások kijelölésével. Ily módon megteremthető lenne a szinergia és a hatékony koordináció a stratégia részét képező (jelenleg projektszinten történő) beavatkozások között. Ehhez elengedhetetlen a szükséges erőforrások biztosítása, illetve a korábban megvalósult, illetve jövőben megvalósuló prevenciós beavatkozások, tevékenységek fenntartása, folytatása.

\section{HIVATKOZÁSOK}

\footnotetext{
${ }^{1}$ Ádány R.: A prevenció helyzete Magyarországon és viszonya a lakosság egészségi állapotából adódó prioritásokhoz OMFB TEP háttéranyag, DOTE Népegészségügyi Iskola, Debrecen, 1998.

2 Bakacs M et al. Egészségjelentés 2016. Információk a népegészségügyi beavatkozások célterületeinek azonosításához a nem fertőző betegségek és az egészségmagatartási mutatók elemzése alapján. szerk.: Varsányi P, Vitrai J. Nemzeti Egészségfejlesztési Intézet, Budapest 2017.

${ }^{3}$ Dr. Kósa K.: Az egészségfejlesztés gyakorlata, Hallgatói kézikönyv; 2015.

${ }^{4}$ Colgrove J.: The McKeown Thesis: A Historical Controversy and Its Enduring Influence: Am J Public Health. 2002 May; 92(5): 725-729. https://www.ncbi.nlm.nih.gov/pmc/articles/PMC1447153/pdf/0920725.pdf (Elérve: 2017. június 29.)

${ }^{5}$ Kishegyi J., Makara P.: Az egészségfejlesztés alapelvei - Az egészségfejlesztés alapvető nemzetközi dokumentumai Országos Egészségfejlesztési Intézet, 2004. pp 9.. (Elérve: 2017. június 29.)

${ }^{6}$ Shanghai Declaration on promoting health in the 2030 Agenda for Sustainable Development, 9th Global Conference on Health Promotion, Shanghai 2016 http://www.who.int/healthpromotion/conferences/9gchp/shanghaideclaration.pdf?ua=1 (Elérve: 2017.06.29.)

${ }^{7}$ Simonyi L. (szerk.) Segédlet az iskolai egészségnevelési, egészségfejlesztési program elkészítéséhez, Oktatási Minisztérium, Budapest 2004. (Elérve: 2017. június 29.)

${ }^{8}$ Füzesi Zs, Tistyán L. Egészségfejlesztés és közösségfejlesztés a színtereken Országos Egészségfejlesztési Intézet, 2004. (Elérve: 2017. június 29.)

${ }^{9}$ Rose, G.: Sick Individuals and Sick Popoulations, International Journal of Epidemiology 1985; Vol. 14, No. 1: 3238

${ }^{10}$ Taylor, B.C., Wilt, T.J., Welch, H.G. Impact of diastolic and systolic blood pressure on mortality: implications for the definition of "normal" J Gen Intern Med (2011) 26: 685. doi:10.1007/s11606-011-1660-6

${ }^{11}$ Mackenbach, J. P.: The population and high-risk approaches European Journal of Public Health, 2012; Vol. 23, No. 6, 909-915

12 Zieliński, A.: Sick people and sick populations - legacy of Geoffrey Rose Przegl Epidemiol 2014; 68: 475 - 479.

${ }^{13}$ Ontario Agency for Health Protection and Promotion (Public Health Ontario), Lu D, Tyler I. Focus on: A proportionate approach to priority populations. Toronto, ON: Queen's Printer for Ontario; 2015..

${ }^{14}$ Frohlich, K. L. et al. Transcending the Known in Public Health Practice The Inequality Paradox: The Population Approach and Vulnerable Populations American Journal of Public Health, February 2008, Vol 98, No.2

${ }^{15}$ Frieden, T. R.: A Framework for Public Health Action: The Health Impact Pyramid, American Journal of Public Health, April 2010, Vol 100, No. 4.

${ }^{16}$ Marmot M, Bell R.: Fair society, health lives. Public Health. 2012;126 Suppl 1:S4-10.

${ }_{17}$ Marmot M, et al.: Consortium for the European Review of Social Determinants of Health and the Health Divide. WHO European review of social determinants of health and the health divide. Lancet. 2012;380(9846):1011-29.
} 